\title{
Economic Aspects of Ecotourism: Wildlife-based Tourism and Its Contribution to Nature
}

\author{
Clem Tisdell*
}

\begin{abstract}
This paper defines ecotourism and outlines possible economic and conservational benefits from developing ecotourism or wildlife-based tourism. It identifies possible economic benefits for local communities and possible economic costs to such communities. A sufficient market does not always exist for wildlife-based tourism to make it economically viable. Therefore, market analysis should be undertaken before promoting the development of wildlifebased tourism. A checklist is provided to give guidance in market appraisal. Even non-consumptive wildlife-based tourism can have adverse environmental consequences. These are listed. Care is needed to avoid these negative consequences and to ensure that local communities obtain adequate economic benefits from the development of wildife-based tourism.
\end{abstract}

\section{Introduction}

Ecotourism, usually a form of nature-based tourism, is often claimed to be one of the fastest growing segments of the tourism market globally. In the last couple of decades, many individuals and bodies e.g. IUCN, have begun to view ecotourism as a kind of economic key for supporting nature conservation. Although this form of tourism is generally nature-based, to qualify as ecotourism it should be careful of the environment. Being careful of the environment, it should help to conserve nature and thereby contribute to the sustainability of tourism reliant on wildlife. Many proponents of ecotourism also argue that an important ingredient of it is the provision of environmental education or knowledge for tourists who participate in it ${ }^{1}$ (Wight, 1993). Such knowledge can make tourists more aware of nature and more supportive of its conservation via changes in their personal behaviour, greater political support and larger financial contributions for such conservation (Tisdell and Wilson, 2002a).

It is also believed that
ecotourism can provide direct
financial support for nature
conservation as well as for local
communities where it occurs. Indeed,
the International Ecotourism
Society's definition of ecotourism

*Professor, School of Economics, The University of Queensland, Brisbane 4072, Australia. 
makes local benefits a requirement for tourism to be classified as ecotourism. It defines ecotourism as "responsible travel to natural areas that conserve the environment and improve the well-being of local people" (Honey, 1999). Sekerciogll (2002) states that "ideally, ecotourism creates a local incentive for conserving natural areas by generating income through operations that are sustainable, lowimpact (environmental and social), low-investment, and locally-owned." The local communities involved are often remote from the main centres of economic activity in most nations, and frequently have limited economic opportunities.

While many benefits from the development of ecotourism are possible, it should also be recognized that not all proposed ecotourism projects are likely to be profitable, that they can result in little or no economic benefit to local communities, may become a drain on finance that could otherwise be used for nature conservation (Tisdell, 1995) and can distort the range of species conserved. This paper considers both the benefits and limitations of ecotourism (and more generally wildlife-based tourism) as a means for conserving nature.

Before discussing such aspects, it is appropriate to consider whether the term 'ecotourism' is a useful one for analyzing wildlife-based tourism. One problem is that the term has become emotionally laden. In the popular mind, 'Ecotourism' is considered to be good. It has a normative connotation. This, combined with a variety and some imprecision in definitions of ecotourism can result in vagueness and claims that nature-based tourist projects are ecotourism projects when in fact they are a threat to nature conservation (Honey, 1999). In scientific work, it may, therefore, be more appropriate to revert to the term wildlife-based tourism and classify this by its different characteristics.

Wildlife-based tourism may be classified in several ways. It may be non-consumptive (as in the case of viewing or watching wildlife, photographing it and so on) or it may be consumptive (as in the case of hunting and fishing). In general, ecotourism has been associated with the non-consumptive passive form of wildlife-based tourism. It needs, however, to be recognized that either form of tourism can be a negative or positive force for nature conservation. Even consumptive wildlife-based tourism can be sustainable if catch is appropriately controlled and it can also be supportive of wildlife conservation. For example, hunting organizations, such as Ducks Unlimited in the US, protect ponds and provide food for migrating ducks and geese. 
Benefits from Ecotourism/Wildlifebased Tourism

Table 1 lists some possible positive and negative impacts of ecotourism/wildlife-based tourism on local communities in terms of its economic impacts. The table makes it clear that special care may need to be taken to make sure that local communities do in fact benefit from a profitable ecotourism development. If, for example, Giant's Tank, near Mannar, is redeveloped and further developed for bird-based tourism, care needs to be taken to ensure that local villagers, especially fishers, are able to earn some additional income e.g. by acting as guides for visitors, providing access to areas by boat for visitors and so on.
In particular, care should be taken to avoid excluding locals from natural areas to provide unhampered access for tourists. Local fisherman in this area can potentially assist tourists in the late afternoon and early morning when opportunities for bird watching are greatest. Especially in the late afternoon, fishing is at low ebb. Furthermore, when water levels in the Tank are high, fishing catches are low and this is likely to be a time when fishers would welcome extra income and employment from tourists. Similar tourism possibilities exist in the shallow marine area as one approaches Mannar.

Table 1: Possible Economic Benefits and Economic Costs to Local Communities of Development of Ecotourism

Economic Benefits Possible

1. Increased local employment and income

2. More regular employment and income throughout year

3. Greater diversification of economic activities, thereby reducing economic risks

4. Opportunities for locally controlled ecotourist-related businesses

Economic Costs Possible

1. Exclusion of locals from ecotourist areas with reduction in income, employment and resource availability to locals

2. Loss of control of ecotourist businesses and resources to outsiders

3. Consequent disruption of the social fabric of the local community 
Development or re-development of these sites for tourism will naturally depend on lasting peace. Possibly in the beginning, it will be specialist birdwatchers who will first return. General tourists will probably need to be enticed with a wider range of attractions e.g. availability of cultural attractions such as local dances, historical features - the fort at Mannar, which is badly in need of preservation, may be an attraction, historical aspects of recent conflicts and so on. The tourist market including the ecotourist market for Vanni will need to be carefully assessed and cautiously developed.

One of the possible benefits of the development of ecotourism or wildlife-based tourism is that the economic returns from engaging in it can exceed the costs involved. This is only possible, however, for a wildlife site if exclusion from the site is easy and not too costly. In such a case, wildlife used for tourism can be directly marketed, and such marketing could be (but need not be) profitable. The level of profitability will depend to some extent on how well the ecotourism business venture is managed and on the nature of the development.

If the wildlife site is a state protected area, its income may come from the following sources: (a) entry fees, camping fees, and other charges levied on visitors and (b) the allocation of government revenues, (c) sales of services and products at the site, (d) donations by visitors and (e) sales of concessions to others to provide products or services at the site e.g. accommodation, food and tours. The funds available to the protected area will, however, depend on institutional arrangements. If income raised has to be paid into consolidated government revenue, no benefit may come directly to the protected area as a result of its income generation activities. On the other hand, if the protected area can retain all or a portion of the funds it collects as a result of charges, this will increase its finances for conservation in the protected area (if its marketing is profitable), and if its public funding is not reduced or reduced to such an extent as to offset its increased finance from marketing the protected area's assets to tourists. Different institutional arrangements will create different financial incentives (disincentives) to engage in ecotourism at the local level and influence whether increased funds as a result of financially successful wildlife-based tourism are likely to be available at the local level.

The institutional factors involved are complex and the actual distribution of funds can be significantly influenced by political factors. For example, while there is general public opposition to the charging of fees for entry to national parks and protected areas in Queensland, rights are sold to tour companies by the Queensland Parks and Wildlife Service (QPWS) to 
bring tourists to the Natural Bridge section of Spring brook National Park in the hinterland of the Gold Coast to view glow worms. Those not on organised tours may still enter free. Tour bus operators, because of their payments, have maintained political pressure on QPWS to upgrade paths, parking areas and so on at the site thereby ensuring that economic benefits from their contributions are spent at the site.

Note, however, that a wildlife site may be of economic benefit to a local community even if it operates at a loss and its operations are covered by the government. Even if visitors are not charged a fee to visit a protected area and it operates at a loss, the site is likely to bring positive economic spill over benefits in many cases to local communities, even though the extent of this benefit will differ. There may be increased local employment in the protected area and nearby businesses may benefit from increased trade as a result of tourists. These spill over economic benefits should favour the provision of/or retention of the wildlife site. If the site plus all of its associated offsite economic activities could show an economic surplus, the provision of the site seems economically worthwhile. If commodities supplied in conjunction with the site are strongly complementary to visits to the site, the whole bundle of commodities involved can virtually be treated as one commodity for the purpose of economic analysis. Indeed, if they are perfect complements, they can be analysed as if a single commodity is involved. The site does not have to have an economic surplus in itself to be economically justified in such cases.

From the point of view of maximising community benefit from a protected area being used for tourism, it should be borne in mind that determining the optimal fee structure is not straightforward. For instance, the fee that maximises total or net receipts from visitors is usually not optimal from a social point of view. Such a fee would amount to a monopoly-price. Such a price is difficult to justify on economic welfare grounds. Economists would favour a lower price as a rule that reflects the additional costs of catering for extra visitors, but might support a higher price if crowding at a site is a concern or if the number of visitors is such as to threaten the conservation objectives of the protected area.

On the other hand, a case could also exist for charging an even lower price or making entry free because of the spill over economic benefits to local townships or communities as a result of increased trade from greater levels of tourism, or because procedures to collect the fee are too costly. Complex issues are clearly involved. 
In many cases, wildlife-based tourism/ecotourism can foster community support for conserving wildlife and areas catering for such tourism and wider political support for nature conservation. It can do this, for instance, through local economic benefits and its education /knowledge impact. Furthermore, involvement of community volunteers in assisting with wildlifebased ecotourism can add to community support. Community volunteers assist with ecotourism, for example, at Mon Repos Conservation Park in Queensland. This Park has an important rookery for loggerhead turtles in the Pacific (Tisdell and Wilson, 2002a). Volunteers help with crowd control, selling items to tourists from the onsite shop and in helping with recording of details of turtles on the beach thereby providing scientific data used by natural scientists. This helps to generate community support for the project.

From a study of visitors to Mon Repos, we found that the experience and the additional knowledge they gained about sea turtles made most more supportive of the conservation of sea turtles and increased their willingness to contribute financially to it (Tisdell and Wilson, 2002a). This seems to be especially the case when the visitors saw sea turtles rather than relied solely on the interpretative facilities about sea turtles at the site. Most visitors increased their economic valuation of sea turtles following their visit, indicated that they would alter their behaviour to be more protective of sea turtles, and were more willing to contribute funds to support conservation of sea turtles.

\section{Limitations of Ecotourism as a Conservation Mechanism}

While ecotourism development can provide extra support for nature conservation, not all areas or sites where wildlife and natural areas occur are capable of supporting profitable ecotourism enterprises. This can even be so if the wildlife involved is spectacular and unique. Factors such as the accessibility of the area to visitors, the prospect of viewing wildlife, the availability of complementary attractions and the cost of visiting the site will influence the economic potential of a wildlife site for ecotourism. However, even sites that are costly to visit can sometimes support commercial ecotourism, as witnessed by the development of ship-based ecotourism in Antarctica. However, in assessing the economic potential of a site for the development of ecotourism, factors listed in table 2 are likely to be relevant. This table highlights the fact that determination of potential gains from ecotourism involves considerable economic assessment. In addition, the actual financial advantage (or disadvantage) from engaging in ecotourism will depend on how well the tourism project is managed. 
Table 2: Potential Negative Effects of Tourism on the Environment Protected Areas: Visitor Impacts that should be Controlled

\begin{tabular}{|c|c|c|}
\hline Factor Involved & $\begin{array}{c}\text { Impact on Natural } \\
\text { Quality }\end{array}$ & Comment \\
\hline Crowding by visitors & $\begin{array}{l}\text { Loss of "wilderness } \\
\text { experience, visitor } \\
\text { disutility, changes in } \\
\text { animals" behaviour, stress } \\
\text { on environment }\end{array}$ & $\begin{array}{l}\text { Irritation, reduction } \\
\text { in quality, need for } \\
\text { carrying-capacity } \\
\text { limits or better } \\
\text { regulation }\end{array}$ \\
\hline $\begin{array}{l}\text { Development of } \\
\text { tourist facilities }\end{array}$ & $\begin{array}{l}\text { Excessive man-made } \\
\text { structures }\end{array}$ & $\begin{array}{l}\text { Unsightly urban-like } \\
\text { development }\end{array}$ \\
\hline \multicolumn{3}{|l|}{ Recreation } \\
\hline Powerboats & $\begin{array}{l}\text { Disturbance of wildlife, } \\
\text { bank erosion }\end{array}$ & $\begin{array}{l}\text { Vulnerability during } \\
\text { nesting seasons, } \\
\text { noise pollution }\end{array}$ \\
\hline Fishing & Access tracks, jetties & $\begin{array}{l}\text { Competition with } \\
\text { natural predators }\end{array}$ \\
\hline Foot safaris & Disturbance of wildlife & $\begin{array}{l}\text { Overuse and trail } \\
\text { erosion }\end{array}$ \\
\hline \multicolumn{3}{|l|}{ Pollution } \\
\hline Noise (radio etc.) & $\begin{array}{l}\text { Disturbance of natural } \\
\text { sounds }\end{array}$ & $\begin{array}{l}\text { Irritation to wildlife } \\
\text { and visitors }\end{array}$ \\
\hline Litter & $\begin{array}{l}\text { Impairment of natural } \\
\text { scene, habituation of } \\
\text { wildlife to garbage }\end{array}$ & $\begin{array}{l}\text { Aesthetic and health } \\
\text { hazard }\end{array}$ \\
\hline Vandalism & $\begin{array}{l}\text { Mutilation and facility } \\
\text { damage }\end{array}$ & $\begin{array}{l}\text { Removal of natural } \\
\text { features }\end{array}$ \\
\hline Feeding of Wildlife & $\begin{array}{l}\text { Behavioural changes with } \\
\text { danger to tourists }\end{array}$ & $\begin{array}{l}\text { Removal of } \\
\text { habituated animals }\end{array}$ \\
\hline \multicolumn{3}{|l|}{ Vehicles } \\
\hline Speeding & Wildlife mortality & $\begin{array}{l}\text { Ecological changes, } \\
\text { dust }\end{array}$ \\
\hline Off-road driving & $\begin{array}{l}\text { Soil and vegetation } \\
\text { damage }\end{array}$ & $\begin{array}{l}\text { Disturbance to } \\
\text { wildlife }\end{array}$ \\
\hline
\end{tabular}




\begin{tabular}{|c|c|c|}
\hline Miscellaneous & & \\
\hline $\begin{array}{l}\text { Souvenir } \\
\text { collection }\end{array}$ & $\begin{array}{l}\text { Removal of natural } \\
\text { attractions, disruptions of } \\
\text { natural processes }\end{array}$ & $\begin{array}{l}\text { Shells, coral, horns, } \\
\text { trophies, rare plants }\end{array}$ \\
\hline Firewood & Habitat destruction & $\begin{array}{l}\text { Interference with } \\
\text { natural energy glow }\end{array}$ \\
\hline $\begin{array}{l}\text { Roads and } \\
\text { excavations }\end{array}$ & Habitat loss, drainage & Aesthetic scars \\
\hline Power line & Destruction of vegetation & Aesthetic impacts \\
\hline $\begin{array}{l}\text { Artificial water } \\
\text { holes and salt } \\
\text { provision }\end{array}$ & $\begin{array}{l}\text { Unnatural wildlife } \\
\text { concentrations, } \\
\text { vegetation damage }\end{array}$ & $\begin{array}{l}\text { Poaching may be } \\
\text { facilitated }\end{array}$ \\
\hline $\begin{array}{l}\text { Introduction of } \\
\text { exotic plants and } \\
\text { animals }\end{array}$ & $\begin{array}{l}\text { Competition with wild } \\
\text { species }\end{array}$ & $\begin{array}{l}\text { Damage to } \\
\text { agriculture }\end{array}$ \\
\hline $\begin{array}{l}\text { Visitors disturb } \\
\text { animals }\end{array}$ & $\begin{array}{l}\text { Reduction in populations } \\
\text { of some animals }\end{array}$ & $\begin{array}{l}\text { Breeding of some } \\
\text { animals disturbed as } \\
\text { well as access to } \\
\text { their food sources }\end{array}$ \\
\hline
\end{tabular}

Source: McNeely, Thorsell, and Ceballos-Lascurain 1992

It is important to realise that ecotourism projects can make economic losses. When this happens they may actually reduce funds available for nature conservation (Tisdell, 1995; 1999). Consequently, ecotourism projects that 'go wrong' can become a threat to conservation. They may, of course, also go wrong for technical rather than economic reasons. For instance, the presence of tourists, even if they engage in nonconsumptive tourism, can destroy native vegetation and disturb wildlife, adversely affecting their reproduction and availability. Even non-consumptive tourism has impacts on the surrounding natural environment. It is necessary to take these into account from a conservation point of view, but these impacts cannot always be perfectly predicted.

A major question that arises in relation to most ecotourism or nature-based development is who benefits in economic terms. To what extent, for instance, are any economic benefits of nature-based tourism in an area shared with local people? What types of mechanisms can be put in place to ensure that locals obtain increased benefits from nature-based tourism and/or to ensure minimisation of their deprivation as a result of 'locking up' natural resources for tourism purposes? For instance, declaration of new protected areas often deprives locals of access to natural resources traditionally used by them and they 
may obtain no employment in the protected area or in any tourism connected with it. While there may always be some local losers from such a development, the availability of at least some local economic benefits is necessary to promote local support for a nature-based development project in an area. Without such support, the long-term success of a conservation project is likely to be in jeopardy. For example, in the absence of local benefits, locals may feel morally justified in continuing to exploit resources in the protected area illegally and enforcement of conservation regulations and laws can then be difficult. In addition, there is the matter of distributional justice or equity to consider. Such issues need to be addressed directly.

If it becomes widely accepted that wildlife-tourism can be commercially viable, there is a risk of politicians and the public believing that most, or even all, nature conservation should be reliant on this financial mechanism. Therefore, public funds for supporting nature conservation may be reduced and nature conservation overall could suffer. In addition, conservation efforts may become concentrated on, or mainly concentrated on, the protection of areas and wildlife able to provide positive financial benefits from tourism. Consequently, natural areas and wildlife that have low economic value for tourism but high non-use economic value may be neglected and not conserved. Even from an economic perspective, this is not optimal. Over-reliance on financial mechanisms can promote an inefficient bias in nature conservation given that the appropriate economic goal for resource is to promote total economic value.

Total economic value has been defined as consisting of economic use value plus non-use economic value (Pearce et al., 1989). These use values may also be considered as direct and indirect values. In a natural area, use value is normally obtained onsite and non-use values are usually more intangible and obtained offsite. Onsite, economic use value of an area may come from ecotourism (widely regarded as a non-consumptive economic use) or from hunting and fishing (a consumptive use). Non-use economic values include existence value (represented by the amount individuals would be willing to pay to know merely that an area or species continues to exist) and bequest value (an economic indication of the desire of individuals to conserve a natural area or species for future generations) and could also contain a further philanthropic element (a desire to keep the resource available to others, not necessarily future generations). Nonuse values are discussed. (Jacobsson and Dragun, 1996) Sometimes, also, option values are included in this 
category. The current classification could be improved but it at least brings attention to the fact that not all attributes of nature conservation can be marketed. The presence of nonmarketable values leads to market failure, that is, failure of market or commercial mechanisms to promote a social economic optimum.

If funding for protected areas or species becomes more and more dependent on their use values or marketed values, there is a danger that this will encourage economic activities to be allowed in protected areas that are at increasing odds with conservation. Not only may tourism be encouraged but concessions may be given in some portions of the protected area for crop growing and the grazing of domestic livestock and so on likely to be in direct conflict with nature conservation goals. This is already the case in some developing countries and is exacerbated by the low incomes paid to park rangers and officials (Tisdell, 1999). While the development of ecotourism can contribute to wildlife conservation, it need not do so (Isaacs, 2000).

Table 3: Checklist on Tourism Potential of Protected Area

(1) Is the protected area

* close to an international airport or major tourist centre?

* moderately close?

* remote?

(2) Is the journey to the area

* Easy (short) and comfortable?

* A bit of an effort?

* Arduous or dangerous?

(3) Does the area offer the following

* "star" species attractions?

* Other interesting wildlife?

* Representative wildlife?

* Distinctive wildlife viewing (on feet, by boat, from hides)?

(4) Is successful wildlife viewing

* Guaranteed?

* Usual?

* With luck or highly seasonal?
(7) Does the area have additional

* high cultural interest?

* some cultural attractions?

* few cultural attractions?

(8) Is the area:

* unique in its appeal?

* a little bit different?

* similar to other visitor reserves?

(9) Does the area have:

* a beach or lakeside recreation facilities?

* river, falls, or swimming pools?

* any other recreation possibilities?

(10) Is the area close enough to other sites of tourist interest to be part of a tourist circuit?

* yes, other attractive sites

* moderate potential

* low or no such potential 
(5) Does the area offer

* Several distinct features of interest?

* More than one feature of interest?

* One main feature of interest?

(6) What standards of food and accommodation are offered?

* high standards

* adequate standards

* rough standards
(11) Is the surrounding area

* of high scenic beauty or intrinsic interest?

$*$ quite attractive?

$*$ rather ordinary?

(12) Is the cost of the visit

$*$ high?

$*$ moderate?

* low?

Source: McNeely, Thorsell, and Ceballos-Lascurain,1992.

\section{Concluding Comments}

The development of commercial ecotourism can increase public support and the total amount of funding available for nature conservation. It can be a positive contributor to the conservation of nature. However, this requires a number of assumptions or conditions to be satisfied and some of these have been outlined in this paper. If these are not satisfied, use of commercial values and ethics in relation to nature conservation can have negative consequences for nature conservation. For instance, the total economic value of nature conservation programs may be reduced by this type of emphasis. When over-emphasis on the commercial value occurs, the holistic picture of economic value is lost. Certainly funds obtained from ecotourism development should not be seen as a complete substitute for public funding of nature conservation. While some substitution might be acceptable, it should not be on a scale that reduces total public funding of nature conservation, nor be such as to cause substantial distortion in favour only of commercially valuable species and areas for ecotourism. Ideally, the development of wildlife-based tourism should contribute positively to the total amount of funds available for nature conservation, add to overall conservation efforts and results in this regard, and provide enhanced economic benefits to local communities. $^{2,3}$ To ensure this, however, requires some precautions to be taken. ${ }^{4}$

\section{Endnotes}

1. As observed by the author in February, 2003, educational and interpretative facilities are absent at many of Sri Lanka's wildlife attractions. This was, for example so, or virtually so, at Pinnawala Elephant Orphanage, at many of the turtle hatcheries between Colombo and Galle and at Uda Wallewe National Park when visited by the author. 
Therefore, they do not satisfy this criterion for ecotourism.

2. Some further discussions of issues raised in this article may, for example, be found in Tisdell (1999, 2001). It might also be noted that economist's interest in these matters can be from many different angles. For instance, they may be interested in the consequences of nature conservation/management from the point of view of,

(i) its contribution to the net economic satisfaction (economic welfare) of the community or

(ii) its impact on the level of income and employment locally or in a particular region.

These are not necessarily the same (Tisdell and Wilson, 2002b). Also techniques, such as the travel cost method, may be used to estimate demand for visits to a natural area. However they are not accurate if applied mechanically.

3. The conflict in the north of Sri Lanka in recent decades has saved many natural areas from 'development'. Peace brings the risk that many such areas could be used for projects involving 'unsustainable development'. In particular, coastal areas in the North risk being utilised for prawn (shrimp) farming. In the South, many such projects have had disastrous economic consequences and have proved to be unsustainable. Hopefully, the North will learn from the South's experience. The development of environmentally friendly tourism seems to be a possible sustainable option. However, tourism development will require appropriate regulation because not all tourism is environmentally friendly or socially acceptable.

4. I wish to thank Ranjith Bandara, Charles Santiapillai, S. Wijeyamohan and Clevo Wilson for useful suggestions on an earlier draft of this paper. The revised version of the paper was presented at the Jaffna University (Vavuniya Campus), Sri Lanka, on Wednesday 12 February 2003, at a Seminar on "Wildlife Conservation and the Economics of Wildlife-Based Tourism in Vanni, Sri Lanka" organised by the Vavuniya Campus Teachers' Association. I am grateful for the invitation to participate.

\section{References}

Honey, M. (1999). Ecotourism and Sustainable Development: Who Owns Paradise? Washington D.C.: Island Press.

Isaacs, J. C. (2000). The Limited Potential of Tourism to Contribute to Wildlife Conservation. Wildlife Society Bulletin. 28:61-69. 
Jacobsson, K. M. and A. K. Dragun. (1996). Contingent Valuation of Endangered Species. Cheltenham U.K.: Edward Elgar.

McNeely, J. A., J. W. Thorsell and Ceballos-Lascurain. (1992). Guidelines: Development of National Parks and Protected Areas for Tourism. Paris: World Tourism Organization, Madrid and United Nations Environment Program.

Pearce, D., A. Markandya and E. G. Barbier. (1989). Blueprint for a Green Economy. London: Earthscan Publications.

Sekerciogll, C. H. (2002). Impacts of Birdwatching on Human and Avian Communities. Environmental Conservation. 29(3):282-289.

Tisdell, C. A. (1995). Investment in Ecotourism: Assessing its Economics.Tourism

Economics. 1(4):375-387.

1999). Biodiversity, Conservation and Sustainable Development: Principles and Practices with Asian Examples. Cheltenham, U.K.: Edward Elgar.

• (2001). Tourism Economics, the Environment and Development: Analysis and Policy. Cheltenham, U.K.: Edward Elgar.

Tisdell, C. A. and Wilson, C. (2002a). Economic, Educations and Conservation Benefits of Sea Turtle Based Ecotourism: A Study Focused on Mon Repos, CRC for Sustainable Tourism. Gold Coast Campus: Griffith University. Heritage Listing of Australian Natural Sites: Tourism Stimulus and it Economic Value. Economic Analysis and Policy. 32(2):27-49.

Wight, P. (1993). Sustainable Ecotourism: Balancing economics, Environmental and Social Goals within an Ethical Framework. Journal of Tourism Studies. 4(2):54-66. 